\title{
Sea pen (Pennatulacea) aggregations on the northern Spanish shelf: distribution and faunal assemblages
}

\author{
Susana Ruiz-Pico ${ }^{1}$, Alberto Serrano ${ }^{1}$, Antonio Punzón ${ }^{1}$, Álvaro Altuna ${ }^{2}$, \\ Olaya Fernández-Zapico ${ }^{1}$, Francisco Velasco ${ }^{1}$ \\ ${ }^{1}$ Instituto Español de Oceanografía de Santander, Promontorio de San Martín s/n, 39004, Santander, Spain. \\ (SRP) (Corresponding author) E-mail: susana.ruiz@st.ieo.es. ORCID iD: http://orcid.org/0000-0003-3610-7662 \\ (AS) E-mail: aserrano@st.ieo.es. ORCID iD: http://orcid.org/0000-0002-7806-8422 \\ (AP) E-mail: antonio.punzon@ @st.ieo.es. ORCID iD: http://orcid.org/0000-0001-6703-7690 \\ (OFZ) E-mail: olaya.fernandez@st.ieo.es. ORCID iD: http://orcid.org/0000-0002-6479-890X \\ (FV) E-mail: francisco.velasco@st.ieo.es. ORCID iD: http://orcid.org/0000-0002-6420-9474 \\ ${ }^{2}$ INSUB, Museo de Okendo, Zemoria, 12, 20013 Donostia-San Sebastián, Spain. \\ (AA) E-mail: alvaro.altuna@telefonica.net. ORCID iD: http://orcid.org/0000-0003-1364-7826
}

\begin{abstract}
Summary: The sea pens Funiculina quadrangularis, Pennatula aculeata, Pennatula phosphorea, Pteroeides spinosum and Veretillum cynomorium are known to be characteristic species of the habitat 'pennatulacean communities on circalittoral and upper bathyal soft bottoms', described recently on the northern Atlantic Spanish shelf under the terms of the EU directives. Distribution, abundance and environmental data collected from 1995 to 2010 in the Northern Spanish Shelf Groundfish Surveys in the Cantabrian Sea and off Galicia (SPNGFS) were analysed. Although low densities of sea pens were commonly found over the years, some aggregations were shown. Multivariate analysis separated the aggregations of $F$. quadrangularis and of Pennatula spp. found on circalittoral soft bottoms. In addition, evidence of aggregations of $F$. quadrangularis on upper bathyal sites was also found. Depth and longitude, which were closely related to organic matter and sediment particle size, were key factors in determining the distribution and abundance of these aggregations. However, very little information on distribution and density of the species $P$. spinosum and $V$. cynomorium was obtained. Details of community composition of F. quadrangularis and Pennatula spp. were studied and compared with those of the OSPAR habitat "sea pen and burrowing megafauna communities" in other areas. The results improve our knowledge concerning sea pen communities in the southern Bay of Biscay and contribute to a global assessment of the status of these communities in the northeast Atlantic.
\end{abstract}

Keywords: sea pens; southern Bay of Biscay; abundance; distribution; habitat.

Agregaciones de pennatuláceos en la plataforma del norte de España: distribución y agrupaciones faunísticas

Resumen: Los pennatuláceos Funiculina quadrangularis, Pennatula aculeata, Pennatula phosphorea, Pteroeides spinosum y Veretillum cynomorium son especies características del hábitat "comunidades de pennatuláceos sobre fondos blandos profundos y circalitorales" descrito recientemente en la plataforma noratlántica española bajo directrices europeas. Datos de distribución, abundancia y ambientales recogidos desde 1995 hasta 2010 en las campañas demersales de la plataforma del norte de España y Galicia (SPNGFS) han sido analizados. Aunque predominan las bajas densidades de pennatuláceos a lo largo de los años, se han encontrado agregaciones. El análisis multivariante ha separado las agregaciones encontradas de $F$. quadrangularis y Pennatula spp. en los fondos blandos circalitorales. Además, se han encontrado agregaciones de $F$. quadrangularis en los fondos blandos profundos. La profundidad y la longitud, estrechamente relacionadas con el contenido de materia orgánica y el tamaño de partícula del sedimento, han sido los factores clave en la distribución y abundancia de estas agregaciones. Sin embargo, se ha obtenido poca información de la distribución y densidad de las especies $P$. spinosum y $V$. cynomorium. Se ha estudiado la composición de las comunidades de $F$. quadrangularis y Pennatula spp. y se ha comparado con el hábitat definido por OSPAR "sea pen and burrowing megafauna communities" en otras áreas. Los resultados mejoran el conocimiento de las comunidades de pennatuláceos en el sur del Golfo de Vizcaya y ayudan en la evaluación global del estatus de estas comunidades en el noreste Atlántico.

Palabras clave: pennatuláceos; sur del golfo de Vizcaya; abundancia; distribución; habitat.

Citation/Como citar este artículo: Ruiz-Pico S., Serrano A., Punzón A., Altuna A., Fernández-Zapico O., Velasco F. 2017. Sea pen (Pennatulacea) aggregations on the northern Spanish shelf: distribution and faunal assemblages. Sci. Mar. 81(3): 413-423. doi: http://dx.doi.org/10.3989/scimar.04359.06A

Editor: M. Ramón.

Received: October 21, 2015. Accepted: Aprill 27, 2017. Published: June 28, 2017.

Copyright: (c) 2017 CSIC. This is an open-access article distributed under the terms of the Creative Commons Attribution (CC-by) Spain 3.0 License. 


\section{INTRODUCTION}

Recent studies and environmental legislation are involving sea pens in habitat conservation (OSPAR 2010, NOAA 2014, Kenchington et al. 2014). Despite their ecological value, pennatulacean coral habitats have been overlooked compared with cold-water coral ecosystems and studies of the latter mainly focus on stony corals (Order Scleractinia), sea fans and soft corals (Order Alcyonacea). Examples of sea pens forming fields (Aguilar et al. 2009, Porporato et al. 2014, Kenchington et al. 2014) and acting as nurseries for fish larvae (Pirtle 2005, Baillon et al. 2012) or as indicators of quality of mud habitats (MacDonald et al. 1996) highlight their role in benthic ecosystems. Like other corals, sea pens are slow-growing species that are particularly vulnerable because recovery after disturbances can take a long time (Kaiser et al. 2006, de Moura Neves et al. 2015). Moreover, in contrast with other corals, they are able to anchor in soft sediment (Hughes 1998), offering a shelter in a bare environment and acting as an indicator of the degradation of these sediments, which commonly sustain intensive fishing pressure or other disturbances (Thrush and Dayton 2002). The OSPAR Convention assessed the threatened habitat "sea pen and burrowing megafauna communities" in the northeast Atlantic affected by $\mathrm{Ne}$ phrops trawling (Hughes 1998, Greathead et al. 2007, OSPAR 2010). Moreover, sea pens are involved in the soft-bottom coral garden habitat that is also considered threatened and/or declining (OSPAR 2008). Outside the OSPAR region, in eastern Canada, the important role of deep-sea pennatulacean corals as biogenic habitats has been reported (Kenchington et al. 2010, Baillon et al. 2014), and in the USA, under the reauthorized Magnuson-Stevens fishery Conservation and Management Act, deep-sea coral areas, including sea pens, have been protected from fishing (NOAA 2014). The Northwest Atlantic Fisheries Organization (NAFO) has also protected sea pen fields on the Flemish Cap.

After OSPAR recommendations to increase knowledge on the "sea pen and burrowing megafauna habitat" in areas where there are insufficient data and intensive fishing, such as the Cantabrian Sea (Sánchez and Olaso 2004, OSPAR 2010, ICES 2012), and under the European Marine Strategy Framework Directive (EU 2008) considerable advances in habitat definition have been made in Spain in the last few years, describing 'the pennatulacean communities on circalittoral and bathyal soft bottoms' in the North Atlantic Marine Area (MAGRAMA 2012). Despite these efforts, there is still limited information on this habitat in the area and it receives little attention and protection.

In the Bay of Biscay and nearby areas, 21 species of sea pens have been reported, 13 of them occurring off Spain south of the $44^{\circ} \mathrm{N}$ parallel (Altuna 2010, Supplementary Material Table S1). During several surveys undertaken every autumn by the Spanish Institute of Oceanography (IEO) in the Cantabrian Sea (southern sector of the Bay of Biscay) and off Galicia, five of these species, Funiculina quadrangularis, Pennatula aculeata, Pennatula phosphorea, Pteroeides spinosum and
Veretillum cynomorium, were found on circalittoral and upper bathyal soft bottoms, sometimes in abundance. Although some of these species are of conservation significance (Hughes 1998, OSPAR 2010), knowledge of them is uneven in this area, with little information on their abundance, distribution and habitat requirements.

$F$. quadrangularis has a worldwide range, being common throughout the North Atlantic and the Mediterranean Sea (Manuel 1981, Gili and Pagès 1987), with a wide bathymetric range from $20 \mathrm{~m}$ to depths of over 3000 m (Tixier-Durivault and d'Hondt 1975, Manuel 1981, López-González et al. 2001). It is a sensitive species considered to be of conservation significance. This species is reported to be especially vulnerable to disturbances because of its inability to withdraw rapidly into the sediment (Hughes 1998). According to the European Nature Information System (EUNIS), it is a characterizing species of the circalittoral biotope 'sea pen and burrowing megafauna', as well as being common in the bathyal facies of soft muds associated with Aporrhais serresianus in the Mediterranean Sea. Furthermore, with the implementation of the MSFD in Spain, specifically in the North Atlantic Marine Area (MAGRAMA 2012), this species is also described as a characterizing species of 'the pennatulacean communities on circalittoral and bathyal soft bottoms' in the northern Atlantic Spanish area.

The genus Pennatula has a worldwide distribution (Williams 2011), and three out of the five species listed by Williams (2014) from the European Register of Marine Species area occur in the Cantabrian Sea off Spain: namely $P$. aculeata, $P$. grandis and $P$. phosphorea. Records of $P$. rubra from this area are misidentifications. The species $P$. aculeata and $P$. phosphorea are often uncertainly classified (Manuel 1981), and the latter has been confused with other species (Hughes 1998). Thus, tracing their distributions is not easy despite the fact that they are accepted species (Williams 2014). Both species may co-occur in some areas and at some depths in the southern sector of the Bay of Biscay and Galicia (Supplementary Material Table S1). P. phosphorea is widespread in the North Atlantic and in the Mediterranean Sea, with several records from the whole Bay of Biscay (Tixier-Durivault and d'Hondt 1975, Gili and Pagès 1987), and is also involved in conservation issues (OSPAR 2010). According to EUNIS classification, it occurs together with Virgularia mirabilis in the biotope 'sea pen and burrowing megafauna' in the North and Irish Sea, but also in the facies of sticky muds with $V$. mirabilis in the Mediterranean Sea. It may also be found in the biotope 'Myrtea spinifera and polychaetes in offshore circalittoral sandy mud' in the North and Irish Sea.

On the other hand, P. aculeata has been mainly reported in the North Atlantic, including the Bay of Biscay, but there are some Mediterranean records as well (Tixier-Durivault and d'Hondt 1975, Langton et al. 1990, Ocaña et al. 2000). A review of the literature (Supplementary Material Table S1) indicates that it can reach deeper depths than $P$. phosphorea in the Bay of Biscay and nearby areas, and it has not been associated with a given habitat. 


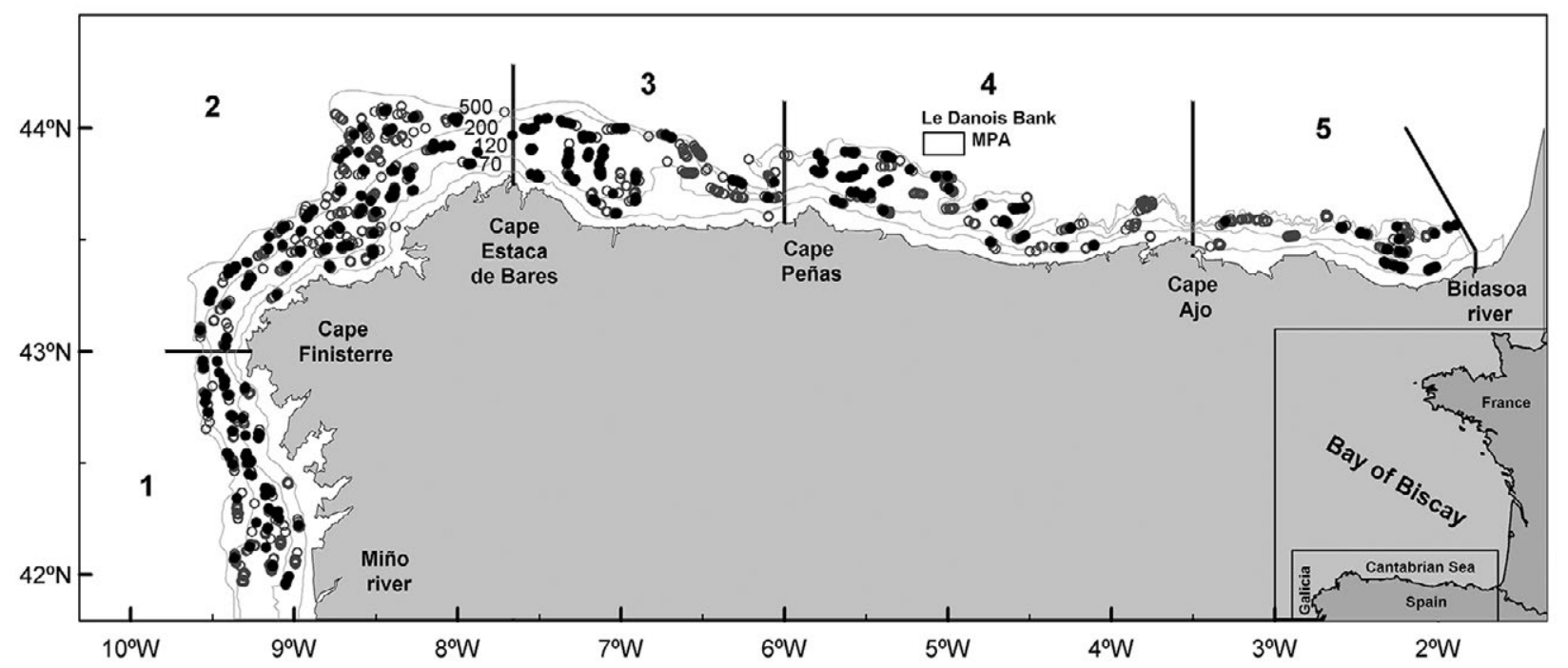

Fig. 1. - Stratification design and hauls (with sea pens, solid black circles and without sea pens, grey circles) in the Northern Spanish Shelf Groundfish Survey. Geographical sectors: 1, Miño-Finisterre; 2, Finisterre-Estaca de Bares; 3, Estaca de Bares-Peñas; 4, Peñas-Ajo; 5, AjoBidasoa. Depth strata: 70-120 m; 121-200 m; 201-500 m; and >500 m.

The two genera Pteroeides and Veretillum are reported in the eastern Atlantic and West Pacific and described to be bathymetrically restricted to shallow waters (Williams 2011). Specifically, the geographical distribution of $P$. spinosum and $V$. cynomorium ranges from the Bay of Biscay to the Atlantic shores of Africa, including the Mediterranean Sea (Gili and Pagès 1987, López-González et al. 2001, Altuna, 2010). They are involved in the habitat 'the pennatulacean communities of circalittoral and bathyal soft bottoms', according to the description of the biodiversity in the North Atlantic Marine Area (MAGRAMA 2012) with the implementation of the MSFD.

The present work considers the biology and ecology of the most abundant sea pens on the shelf and in the upper bathyal of the southern Bay of Biscay and northwestern Spain (Galicia), mapping their distribution, identifying significant concentrations and describing the benthic/demersal communities associated with them.

\section{MATERIALS AND METHODS}

\section{Study area}

The study area is the northern Spanish shelf in the southern Bay of Biscay (Fig. 1). This area is included in the OSPAR Region IV in the northeast Atlantic and in the ICES Ecoregion Bay of Biscay and the Iberian Coast. It is situated at temperate latitudes and is strongly influenced by the inflow of oceanic water from the Atlantic Ocean. The bottom topography is highly variable, with noteworthy features such as seamounts, banks and submarine canyons, and a highly diverse coastline. The westernmost area (Galician shelf) in particular is fed by many rias and the large Miño River and has a wider shelf, whereas the eastern area (Cantabrian Sea) is cut by many canyons, the shelf is narrower and the slope steep. The former area falls within ICES Division IXa and the latter within Division VIIIc.
In addition, the Le Danois Bank, the Galicia Bank and the Avilés Canyon have been detected as vulnerable ecosystems off the shelf in the study area and proposed as a Marine Protected Area (MPA).

\section{Data source}

The study area has been sampled annually for 33 years by a Spanish groundfish survey to collect demersal and benthic megafauna data, oceanography and sediment characteristics, as described by Olaso (1990) and the standard International Bottom Trawl Survey (IBTS) methodology (ICES 2010). These data were used to analyse changes in the distribution and abundance of the pennatulaceans from the families Funiculinidae, Pennatulidae and Veretillidae from 1995 to 2010 .

Following the IBTS methodology (ICES 2010), hauls of 30 minutes (ca. 126 hauls per survey) were performed at a speed of 3 knots with an otter trawl sampler (baca 44/60) with a $20 / \mathrm{mm}$ mesh cod-end liner and a mean swept area of $52504 \mathrm{~m}^{2}$. The sampling design used was random stratified to the area, with five geographical sectors and three depth strata, two on the circalittoral $(70-120 \mathrm{~m}, 121-200 \mathrm{~m})$ and one on the upper bathyal (201-500 m) (Fig. 1). In addition, some extra hauls were carried out to cover shallower $(<70 \mathrm{~m})$ and deeper $(>500 \mathrm{~m})$ grounds.

The environmental variables depth, near-bottom temperature and salinity, location (longitude) and sediment characteristics were analysed to explain differences among the samples. Temperature and salinity were measured with a CTD Seabird 25. Sedimentary characteristics were determined using a sediment collector attached to the groundgear. Particle size of sediments was analysed by combining dry sieving and sedimentation techniques and the variables weight percentage of gravel and coarse sands (GCS: $>500 \mu \mathrm{m}$ ), weight percentage of medium, fine and very fine sands (MFS, 63-500 $\mu \mathrm{m}$ ) and 
weight percentage of silt $(<63 \mu \mathrm{m})$. In addition, weight percentage of organic matter $(\mathrm{OM})$ in the sediment was estimated as weight loss of dried $\left(100^{\circ} \mathrm{C}, 24 \mathrm{~h}\right)$ samples after combustion $\left(500^{\circ} \mathrm{C}, 24 \mathrm{~h}\right)$.

\section{Data analysis}

Density (number of colonies per haul) of F. quadrangularis, Pennatula spp., $P$. spinosum and $V$. cynomorium were obtained from the 2019 hauls (standard and extra hauls) performed between 1995 and 2010 . In addition, records of Pennatula spp. collected on the same surveys but from 2008 and 2014 were used to shed some light on the bathymetric distribution of the two species $P$. aculeata and $P$. phosphorea, although they were not included in the density analysis.

The aggregations at or above 10.5 sea pens/haul were studied to analyse faunal assemblages, according to the threshold defined under the MSFD, of species forming habitat when abundances are at or above 200 individuals $\mathrm{km}^{-2}$ or biomass at or above $4 \mathrm{~kg} \mathrm{~km}^{-2}$ in the same area as our study area, the North Atlantic Marine Area (MAGRAMA 2012). We chose the threshold based on abundance because the biomass of sea pens is not an accurate measurement at sea for these lightweighing species.

An abundance matrix of demersal species was obtained. Highly abundant mobile invertebrates such as the decapod Polybius henslowii, swimming pelagic crustaceans and nektonic cephalopods, namely squids, were removed from the data set.

Density of sea pens per haul was plotted on a histogram and on a spatial context in the area to study the aggregations. Species accumulation curves were represented with the "vegan" package in R software (R Core Team 2014) to ensure that the aggregations were adequately sampled.

Environmental differences between aggregations were studied with constrained correspondence analysis (CCA) and implemented with R (Borcard et al. 2011). Unlike in unconstrained ordination, in canonical ordination the data matrix is forced or constrained by the environmental variables and performs well with species abundance data (Palmer 1993). Forward selection was used for variable reduction and partial CCA to study the effect of correlation and the power of the most significative variables when the other variables were controlled. The significance of the F-statistics associated with all variables was tested using permutation tests, and the most significant explanatory variable was selected (Blanchet et al. 2008). Significance of the adjusted model with the most significant variables was tested using an ANOVA-like permutation test for CCA. CCA results were presented graphically in a tridimensional ordination diagram generated by triplot scaling focusing on inter-species distances, in which samples were represented by symbols, species by points and environmental variables by vectors. In addition, a Mantel correlogram of the Bray-Curtis similarity matrix of the aggregations was constructed to evaluate the spatial correlation as a function of the geographic distance classes.
Table 1. - Summary of the collection data from 1995 to 2010 . N, number of hauls analysed; Nseapens, number of hauls with seapens; Naggreg.C, number of hauls with densities at or above the threshold 10.5 sea pens/haul on the circalittoral; Naggreg.U, number of hauls with densities at or above the threshold 10.5 sea pens/haul on upper bathyal.

\begin{tabular}{lcccc}
\hline Year & $\mathrm{N}$ & Nseapens & Naggreg.C & Naggreg.U \\
\hline 1995 & 116 & 18 & 6 & 1 \\
1996 & 114 & 32 & 6 & 2 \\
1997 & 116 & 36 & 12 & 1 \\
1998 & 114 & 22 & 1 & 0 \\
1999 & 116 & 15 & 4 & 1 \\
2000 & 113 & 12 & 2 & 1 \\
2001 & 113 & 20 & 0 & 0 \\
2002 & 109 & 20 & 3 & 0 \\
2003 & 112 & 17 & 2 & 1 \\
2004 & 114 & 29 & 4 & 1 \\
2005 & 116 & 41 & 5 & 0 \\
2006 & 116 & 40 & 1 & 1 \\
2007 & 117 & 29 & 5 & 0 \\
2008 & 115 & 22 & 2 & 0 \\
2009 & 119 & 23 & 2 & 0 \\
2010 & 114 & 27 & 1 & 1 \\
\hline
\end{tabular}

Differences of the species composition between aggregations were studied with PRIMER version 6.1.13 (Clarke and Gorley 2006). Analysis of Bray-Curtis similarity (ANOSIM) was used to detect the statistical significances of these differences, and the similarity of percentages procedure (SIMPER) was used to identify higher-contributing species (at least 80\%) to intragroup Bray-Curtis similarity and intergroup dissimilarities. In addition, the frequency and density of the species composition of the aggregations were obtained. Categories of the percentage of occurrence were established according to biotopes classification for Britain and Ireland and categories of density were based on a modified SACFOR scale (semiquantitative abundance scale, Connor et al. 2004), but reduced to four categories (Abundant, $>1000 /$ haul; Common, 100-999/haul; Frequent, 10-99/haul; and Occasional, $1-9 /$ haul) due to the low abundances found in the study area.

\section{RESULTS}

\section{Distribution of sea pens in the area}

Approximately $21 \%$ of the hauls were found to contain sea pens every year. The summary of these hauls with sea pens is shown in Table 1. In general, the density was low: around $65 \%$ of the hauls with sea pens showed an abundance of one colony per haul. Despite this predominance of low densities, evidence of aggregations was found during the time series (Table 1 and Fig. 2) and throughout the study area (Fig. 3). Approximately $20 \%$ of the hauls with sea pens were found to contain densities of sea pens at or above the threshold of 10.5 sea pens per tow. In addition, the Mantel correlogram showed a positive spatial correlation among near samples and negative significance in distant samples, supporting the hypothesis that sea pens form aggregations across space in the area (Supplementary Material Fig. S1). Species accumulation curves for these aggregations (Supplementary Material Fig. S2) indicated a suitable sampling. 


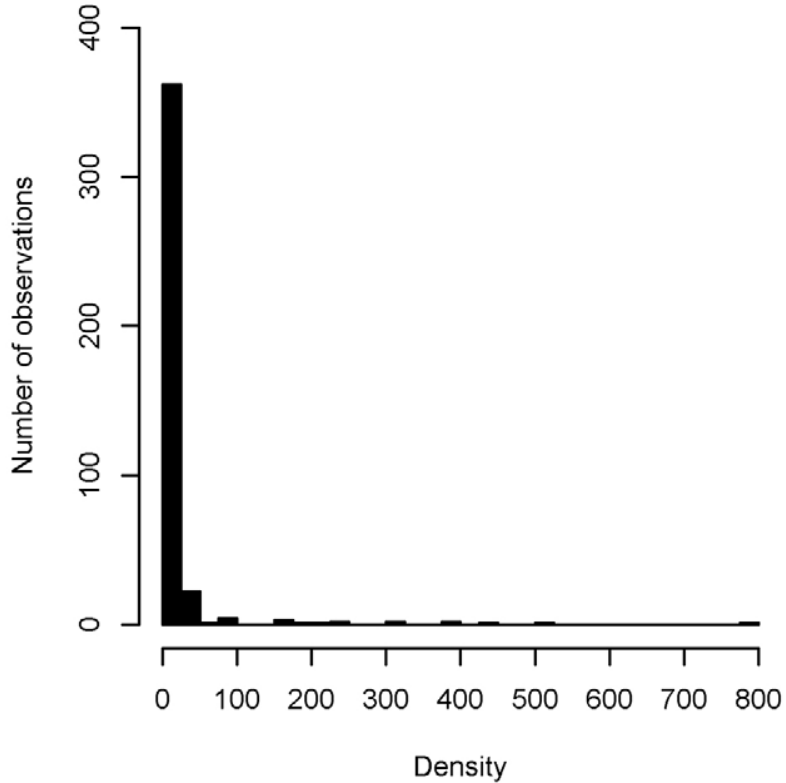

Fig. 2. - Density for all non-zero data of sea pens (colonies/haul).

The results of CCA (Fig. 4A and Table 2) showed that the first axis (Eigenvalue=0.822) splits the aggregations into two groups, depth being the most contributing variable, with higher scores associated with deeper aggregations. The second axis (Eigenvalue $=0.467$ ) also splits the sites into two groups, but in this case the most contributing variables were mainly $\mathrm{OM}$ and longitude, with negative scores associated with western stations. The two groups of the first axis corresponded to the circalittoral (negative scores) and upper bathyal (positive scores) aggregations, and the two groups of the second axis corresponded to the aggregations on the circalittoral of $F$. quadrangularis (positive scores) and Pennatula spp. (negative scores). Therefore, three groups were defined in the study area as the results of the CCA: the aggregations of $F$. quadrangularis on the circalittoral, the aggregations of $F$. quadrangularis on the upper bathyal and the aggregations of Pennatula spp. on the circalitttoral. Some aggregations on the upper bathyal were slightly deeper than $201 \mathrm{~m}$, so they were at the border between the circalittoral and the upper bathyal. In fact, they were closer to the groups of aggregations on the circalittoral than to the group on the upper bathyal, as is shown in the CCA.

Forward selection showed a significant model ( $\mathrm{p}>0.005)$ with depth, OM and salinity. Partial CCAs highlighted that depth, and to a lesser extent longitude, were the variables which best defined the groups of aggregations when the other variables were partialled out.

Most of the aggregations (80\%) were on the circalittoral between 94 and $196 \mathrm{~m}$, but some aggregations
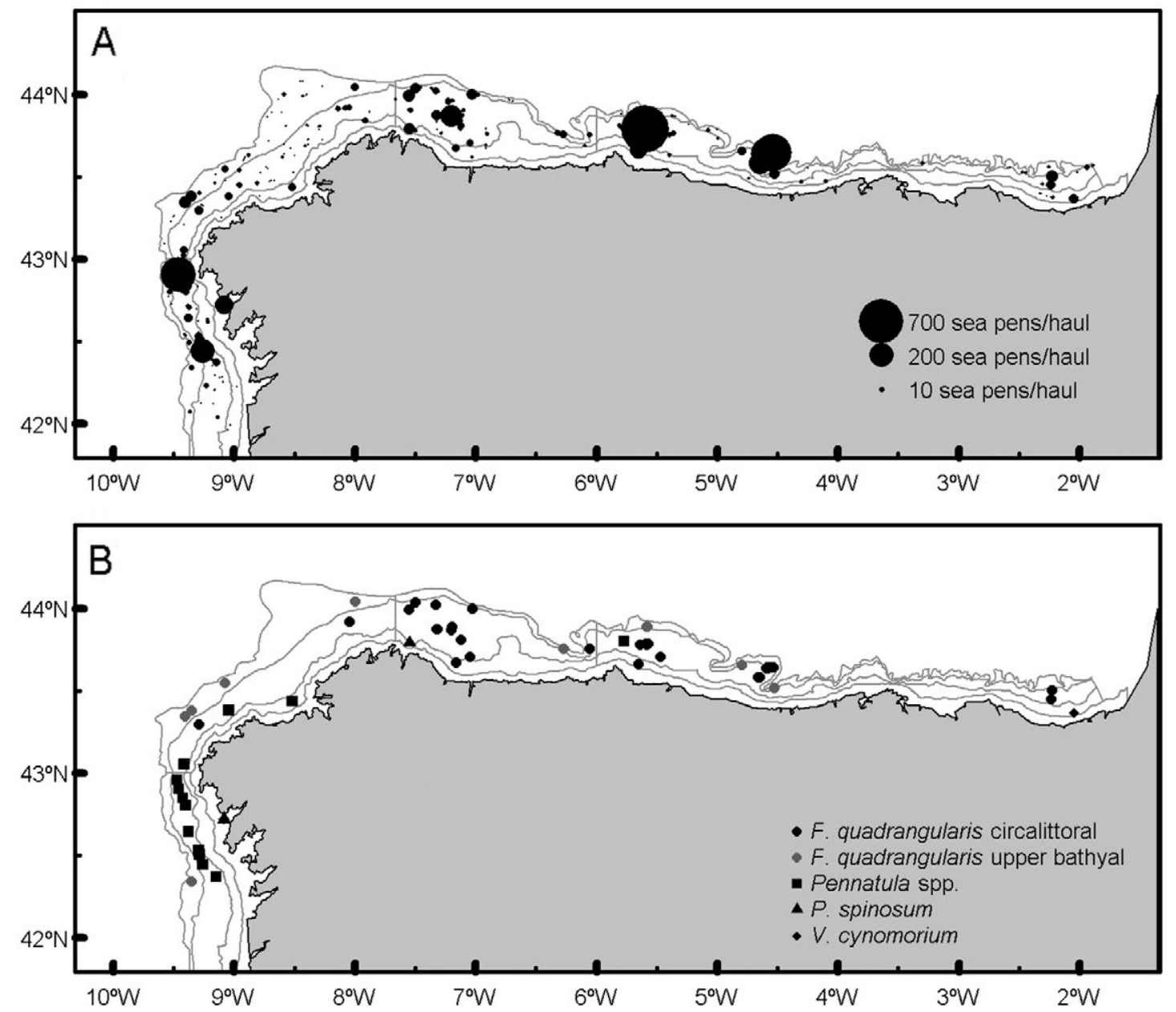

Fig. 3. - Distribution of sea pens (A) and of the aggregations (B) in the study area. 

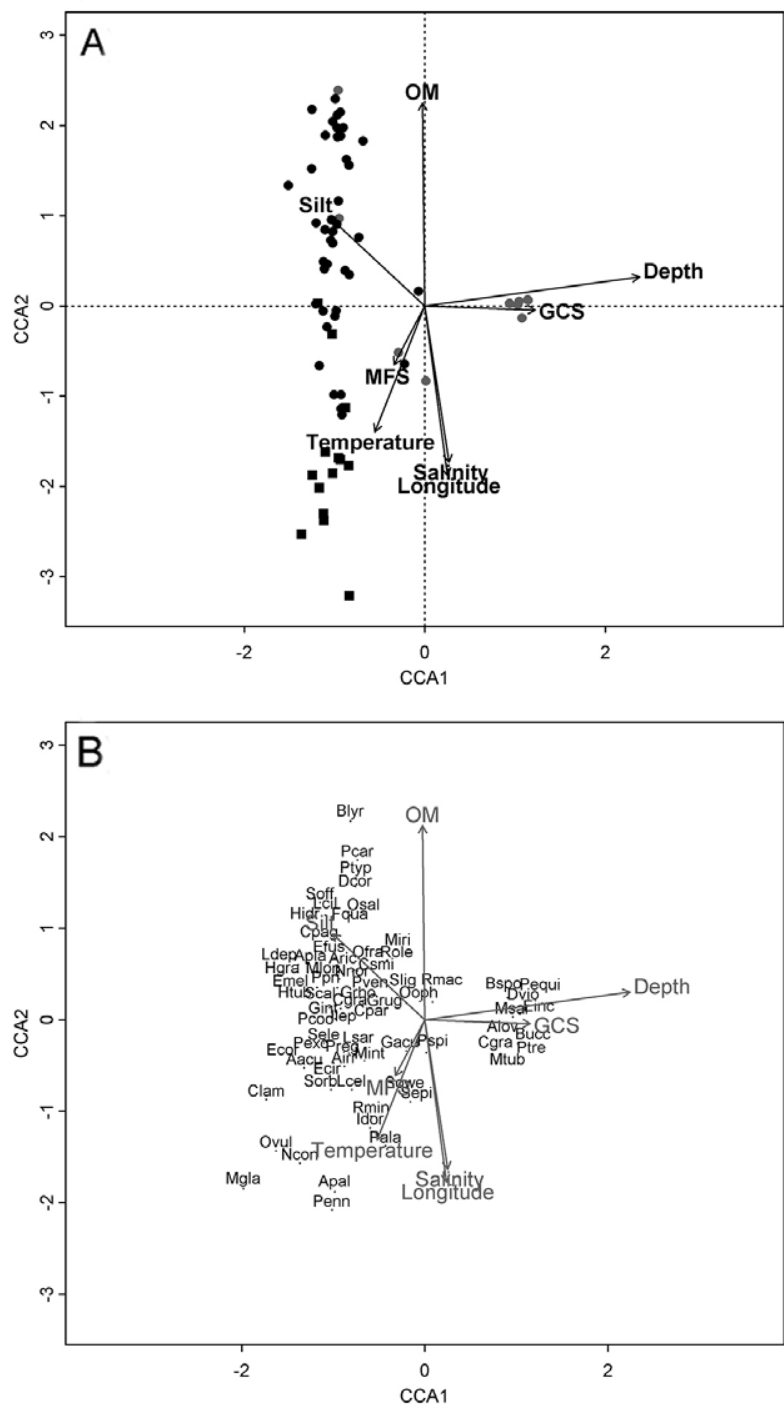

Fig. 4. - A, CCA of the aggregations (F. quadrangularis [dots] and Pennatula spp. [squares]) based on the species composition. The samples on the circalittoral in black and the samples on the upper bathyal in grey. B, CCA of the species composition of these aggregations. Species abbreviations appear in Supplementary Material Table S2. The arrows indicate the direction and magnitude of the environmental variables: depth, longitude, temperature, salinity, median particle diameter (GCS, weight percentage of gravel and coarse sands [ $>500 \mu \mathrm{m}]$; MFS, weight percentage of medium, fine and very fine sands [63-500 $\mu \mathrm{m}]$; Silt, percentage weight of silt $[<63$ $\mu \mathrm{m}])$ and weight percentage of organic matter (OM).

were also found on the upper bathyal from $194 \mathrm{~m}$ to $300 \mathrm{~m}$. On the circalittoral, approximately $73 \%$ of the aggregations were dominated by $F$. quadrangularis, $25 \%$ by Pennatula spp., $1 \%$ by $P$. spinosum and $1 \%$ by $V$. cynomorium. On the upper bathyal, all aggregations were dominated by $F$. quadrangularis (Fig. 3B).

$F$. quadrangularis was the most abundant sea pen in the study area. This species represented about $83 \%$ of the pennatulacean mean abundance caught with an average of 23 colonies per haul. F. quadrangularis was widespread in the sampling area from 84 to $793 \mathrm{~m}$.

Pennatula spp. represented about $14 \%$ of the mean abundance of pennatulaceans caught. Despite their low percentages, Pennatula spp. was found every year, with an average of nine colonies per haul. It was
Table 2. - Canonical coefficients for each environmental variable on each canonical axis (CCA) on the aggregations of $F$. quadrangularis and Pennatula spp. GCS, weight percentage of gravel and coarse sands $(>500 \mu \mathrm{m})$; MFS, weight percentage of medium, fine and very fine sands $(63-500 \mu \mathrm{m})$; Silt, percentage weight of silt $(<63$ $\mu \mathrm{m})$; OM, weight percentage of organic matter.

\begin{tabular}{lcc}
\hline & CCA1 & CCA2 \\
\hline Longitude & 0.10 & -0.72 \\
Depth & 0.91 & 0.12 \\
Temperature & -0.21 & -0.54 \\
Salinity & 0.10 & -0.67 \\
OM & -0.01 & 0.86 \\
GCS & 0.47 & -0.02 \\
MFS & -0.13 & -0.25 \\
Silt & -0.41 & 0.38 \\
\hline
\end{tabular}

mainly found in the Galician area from 91 to $793 \mathrm{~m}$, with two species identified, namely $P$. aculeata and $P$. phosphorea. All specimens verified as $P$. aculeata in the study area occurred deeper than $700 \mathrm{~m}$, while those of $P$. phosphorea were caught on the shelf (Supplementary Material Table S1). Among the few colonies of $P$. aculeata identified, four were found at $793 \mathrm{~m}$ on the surrounding slope of the Le Danois Bank MPA and, out of the study time series, three colonies were found at $811 \mathrm{~m}$ in the southwest of the Le Danois Bank MPA in 2013 and 2014 (unpublished data).

$P$. spinosum represented a small percentage of the mean abundance of pennatulaceans caught (3\%), but it was found every year from a minimum of 1 colony to a maximum of 42 colonies per haul and with an average of 3 colonies per haul. $P$. spinosum occurred from $50 \mathrm{~m}$ to $296 \mathrm{~m}$, although it was mostly found shallower than $150 \mathrm{~m}$. Two aggregations were found, one in Galician waters at a depth of about $48 \mathrm{~m}$ and one in the western Cantabrian Sea at about $120 \mathrm{~m}$ (Fig. 3B).

$V$. cynomorium was scarce in the sampling area and it was not found every year. A maximum of 118 colonies per haul was found in 2009 at about $50 \mathrm{~m}$ depth in the Galician area, although this species mainly ranged between 90 and $170 \mathrm{~m}$ in the easternmost area of Cantabrian Sea and exceptionally occurred around $370 \mathrm{~m}$. Two aggregations were found, one together with the aggregation of $P$. spinosum in the southern Galician waters and one in the easternmost area of Cantabrian Sea at about $98 \mathrm{~m}$ (Fig. 3B).

The density of these two last species may be underestimated in the present study as depths shallower than $70 \mathrm{~m}$ were under-sampled. This scarcity prevented us from assessing their ecological importance.

\section{Faunal assemblages}

Aggregations of Funiculina quadrangularis on circalittoral and upper bathyal soft bottoms

The aggregations of $F$. quadrangularis were mainly found on the circalittoral of the central area of the Cantabrian Sea between 95 and $301 \mathrm{~m}$ (80\%), although, as stated above, some aggregations were also observed on the upper bathyal in the study area (Fig. 3B).

Differences in species composition between aggregations on the circalittoral and the upper bathyal and ecological information of species were obtained by 


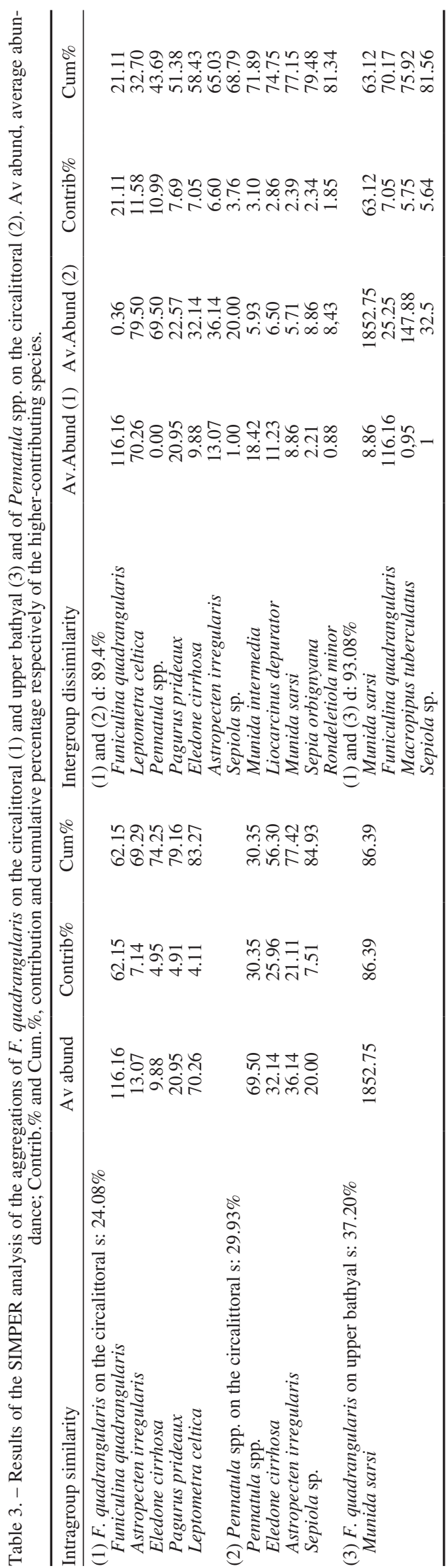

combining the results of CCA (Fig. 4B), the density data (Supplementary Material Table S2) and SIMPER (Table 3). ANOSIM identified significant dissimilarities between the samples of $F$. quadrangularis on the circalittoral and the samples on the upper bathyal $(\mathrm{R}=0.678 ; \mathrm{p}=0.001)$, and the SIMPER showed an intergroup dissimilarity between these groups of $93.1 \%$. The SIMPER results showed that the species Munida sarsi, F. quadrangularis, Macropipus tuberculatus and Sepiola sp. mainly drove the intergroup dissimilarities. In the shallower (circalittoral) aggregations, the species $F$. quadrangularis and the crinoid Leptometra celtica showed the highest densities, although the highest-contributing species to the similarity were $F$. quadrangularis, the seastar Astropecten irregularis, the cephalopod Eledone cirrhosa, the hermit crab Pagurus prideaux and $L$. celtica. In the deeper aggregations, M. sarsi overshadowed the rest of the species due to its high density and contribution to the communities. If we do not cut off the low contributions, we can see that the cephalopod Sepiola sp., $F$. quadrangularis and the portunid crab $M$. tuberculatus contributed $4.82 \%, 3.15 \%$ and $1.66 \%$, respectively. Regarding density, M. tuberculatus was the second most abundant species despite its lowest contribution.

In addition, the CCA (Fig. 4B) confirmed the segregation of samples into two groups together with a segregation of species. The eurybathic species were found in both aggregations and located near the CCA centroid, but the positive axis 1 of CCA also showed species with deeper habits and associated with larger sediment (GCS) on upper bathyal soft bottoms, and the negative axis 1 of CCA showed species with shallower habits and associated with fine sediment (silt and MFS) on circalittoral soft bottoms.

The results of the Mantel correlogram (Supplementary Material Fig. S1) also confirmed a variability of species composition along a spatial gradient. The species composition of the aggregations was significantly spatially similar at short distances, whereas when they were spatially separated they did not show significant similarity.

\section{Aggregations of Pennatula spp. on circalittoral soft bottoms}

The aggregations of Pennatula spp. were mainly found on the circalittoral in the southern Galician area between 95 and $179 \mathrm{~m}$. No evidence of aggregations was found on upper bathyal (Fig. 3B).

Differences of species composition between the aggregations on the circalittoral of $F$. quadrangularis and Pennaluta spp. were found (CCA [Fig. 4B], density data [Supplementary Material Table S2] and SIMPER [Table 3]). ANOSIM identified significant dissimilarity between these samples on the circalittoral $(\mathrm{R}=0.629 ; \mathrm{p}=0.001)$, and the SIMPER showed an intergroup dissimilarity between groups of $89.4 \%$. The SIMPER showed that the species $F$. quadrangularis, the crinoid L. celti$c a$, Pennatula spp., the hermit crab P. prideaux, the cephalopod E. cirrhosa, the seastar A. irregularis, the cephalopod Sepiola sp., the anomuran crab Munida intermedia, the portunid crab Liocarcinus depurator, the anomuran crab M. sarsi, and the cephalopods Sepia orbygnyana and Rondeletiola minor mainly drove the intergroup dissimilarities between the aggregations of $F$. quadrangularis and of Pennatula spp. on the circalittoral in descending order of contribution. In the aggregations of Pennatula spp., the species, E. cirrhosa, A. irregularis and Sepiola sp. were the highest-contributing species to the similarity. 


\section{DISCUSSION}

Our results provided further evidence of sea pens in the southern Bay of Biscay. Pennatulaceans have been previously reported in the area, not only in the proposed MPAs on the Galicia Bank (IEO 2014a) and in the Avilés Canyon (IEO 2014b), but also in the inner basin of the Le Danois Bank MPA (BOE 2011) and in Galician waters (Aguilar et al. 2009). Moreover, under the MSFD, Spain has recently identified pennatulacean communities as the most diverse and richest habitats on circalittoral and bathyal soft bottoms of the northern Atlantic Spanish area (MAGRAMA 2012). Our results also provided further evidence of sea pens forming aggregations on the northern Atlantic Spanish shelf. Although sea pens were broadly found at low density in the study area, the aggregations with a noteworthy high density in the central part of the Cantabrian Sea and in the southern Galician area and the high spatial autocorrelation among near samples supports the hypothesis of sea pens forming aggregations in the area. The hotspots in the Cantabrian Sea were of the species $F$. quadrangularis, while in the Galician area they were of Pennatula spp. Though the sea pens $V$. cynomorium and $P$. spinosum were scarce, they showed two hotspots in the southern Galician area and in the easternmost area of the Cantabrian Sea, respectively.

In addition, differences in the distribution of sea pen aggregations were supported by the fact that longitude was among the variables contributing most to the differentiation of the aggregations. This factor is a result of environmental differences between the western (Galicia area) and eastern (Cantabrian Sea) zones of the study area, the Galician and Cantabrian Sea, respectively. In general, there is higher primary production in Galician waters (López-Jamar et al. 1992, OSPAR 2000) and, in particular, a heterogeneous grain size and a higher OM content have been reported to the south of Cape Finisterre (López-Jamar et al. 1992), where Pennatula spp. was highly abundant. Pennatula spp. are known to be much stouter and fleshier than $F$. quadrangularis (Manuel 1981), which probably helps them to settle in less homogeneous sediments. In fact, both species are known to occur in muddy substrata, but Manuel (1981) also reported P. phosphorea in sandy substrata and Greathead et al. (2015) reported the absence of $F$. quadrangularis in sediment with gravel content above $30 \%$.

In addition, longitude also means differences in topography, which leads to an apparent absence of aggregations of sea pens on the narrow shelf and steep slope of the eastern part of the Cantabrian Sea, with the exception of the easternmost shelf area. Therein, mud deposits (Jouanneau et al. 2008) could be supporting the settlement of the few aggregations of $F$. quadrangularis.

On the other hand, depth was also an influential factor in the distribution of the sea pens in the study area. The few aggregations of $P$. spinosum and V. cynomorium were found at about $50 \mathrm{~m}$ depth, although some specimens were recorded at unusual depths in the area if compared with data in the literature (Supplementary
Material Table S1). We found that $70 \%$ of the occurrences of $V$. cynomorium in our study area were detected above $100 \mathrm{~m}$ and three colonies were even found at an unusual depth of $372 \mathrm{~m}$, despite the fact that these two species are known to be continental-shelf species with a distribution related to terrigenous sediments (Gili and Pagès 1987, Williams 2011, Sardá et al. 2012). LópezGonzález et al. (2001) reported, in the eastern Atlantic, a wider depth range (25-188 $\mathrm{m})$ than Williams (1990, 13-91 m), and Gili and Pagès (1987) showed an even deeper limit in the Mediterranean Sea (around $260 \mathrm{~m}$ ). However, neither of them mentioned such a deep distribution for the species. In addition to this interesting result, the highest aggregation of colonies of $V$. cynomorium (118 colonies), together with some colonies of $P$. spinosum (19 colonies), were found near the Arousa Ría (Galicia, Spain), where fields of $V$. cynomorium have been previously reported (Fernández et al. 2005, Aguilar et al. 2009). This result provides further evidence of sea pens forming aggregations, widely recognized as key benthic habitats (OSPAR 2008, DFO 2010, Kenchington et al. 2011).

Another result of the influence of depth on the distribution of sea pen species was found in the Galician area, where Pennatula spp. was abundant from 100 to $200 \mathrm{~m}$, while the few occurrences of $F$. quadrangularis were mainly between 200 and $300 \mathrm{~m}$. Hughes (1998) and Greathead et al. (2007) also suggest the preference of $F$. quadrangularis for deeper habitats where the conditions may be more stable. In addition, also relating depth to sediment particle size and organic content, finer and organic-rich sediments have been reported on the inner shelf off the Rías Bajas (Galicia, Spain), where Pennatula spp. was more abundant, while on the outer shelf the sediments are sandier and have low organic content (López-Jamar et al. 1992). Nevertheless, Greathead et al. (2007) suggest that depth is a more important factor than sediment type in the distribution of $F$. quadrangularis.

Tracing the distributions and bathymetric ranges of $P$. phosphorea and $P$. aculeata in the Bay of Biscay and nearby areas from the literature is not easy, as we highlighted in the Introduction. However, our results provide evidence of different bathymetric distributions between the two species. Hence, the fact that $P$. aculeata extends deeper than $P$. phosphorea suggests that the aggregations of Pennatula spp. found in the study area do not include specimens of $P$. aculeata but only of $P$. phosphorea, although more data are still sorely needed. $P$. aculeata has also been found at similar depths in the southern Bay of Biscay, as a result of the bathyal surveys carried out by the ECOMARG project (www.ecomarg.com). During these surveys, P. aculeata was found only at 745 and $761 \mathrm{~m}$ in the Le Danois Bank MPA, at $786 \mathrm{~m}$ on the Galicia Bank (northwestern Spain) and at $828 \mathrm{~m}$ in the Avilés Canyon (northern Spain) (A. Altuna, personal communication). All these records of upper bathyal presence of $P$. aculeata, and to a large extent, the lack of reliable data of $P$. phosphorea from these areas, highlight the need for more research on the bathymetric distribution and ecological needs of these two species. 
With respect to the sampling of sea pen communities in the southern Bay of Biscay, the present study adds long-term information on the distribution of sea pens in an extensive area, despite the use of trawling sampling. Techniques such as beam trawl and demersal otter trawl are often used in benthic community studies, although monitoring is extensively recommended for the management of sea pens and burrowing megafauna (Hughes 1998, Greathead et al. 2007). Monitoring and assessment of vulnerable habitats have been carried out in the area with non-destructive monitoring techniques such as remotely-operated vehicles and photogrammetric sledges (Aguilar et al. 2009, www.ecomarg.com, Sánchez et al. 2009), but they were short-term or spatially isolated studies. In addition, sampling of some sea pen communities is not easy and very inaccurate, as some pennatulaceans can withdraw below the sediment surface and bias the results of monitoring. The density of some such sea pens in a given area can change by over 200\% in a few hours (Birkeland 1974). Virgularia mirabilis is known to withdraw into the sediment and $P$. phosphorea and $P$. aculeata are also able to do so, although not as quickly, but $F$. quadrangularis, $P$. spinosum and $V$. cynomorium do not show this feature (Langton et al. 1990, Hughes 1998).

The species composition of the aggregations of sea pens in the study area agrees with previous studies in the area, which showed depth as a key factor structuring communities (Olaso 1990, Serrano et al. 2006). Many species that occur in the aggregations of $F$. quadrangularis and Pennatula spp. coincided with the eurybathic species described in the area by Olaso (1990), such as the portunid crab Liocarcinus depurator, the spider crab Macropodia longipes and the sea snail Neptunea contraria, or with the characteristic species of the shelf (between 140 and $300 \mathrm{~m}$ ), such as the sea anemone Actinauge richardi, the sea snail Ranella olearium and the sea cucumber Parastichopus regalis. Specifically in the shallower samples of $F$. quadrangularis, the higher-contributing species Astropecten irregularis, Eledone cirrhosa, Pagurus prideaux and Leptometra celtica were reported by Olaso (1990) on the upper edge of the shelf (between 90 and $140 \mathrm{~m}$ ), whereas the anomuran Munida sarsi, as the most abundant and the highest-contributing species in the deeper samples of $F$. quadrangularis, was reported as a dominant species on the shelf. This author compared the different distribution of $M$. sarsi with the other common anomuran in the area, Munida intermedia and described both species as dominant species on the shelf, but $M$. sarsi showed greater density at $275 \mathrm{~m}$ in the Cantabrian Sea, and $M$. intermedia showed greater density at $175 \mathrm{~m}$ in the Galician area. This explains the higher abundance of $M$. sarsi in the deeper aggregations of sea pens in the area and the greater occurrence of $M$. intermedia in the aggregations of Pennatula spp., which are mainly distributed in Galician waters. In addition, Olaso (1990) and Serrano et al. (2006) showed depth and sediment characteristics to be priority factors determining species composition.

Large differences were found between the aggregations described in the present study and the habitat "sea pen and burrowing megafauna communities" defined by OSPAR. This habitat was reported in the North Sea, the Irish Sea and the Bay of Biscay and may include populations of $V$. mirabilis, $P$. phosphorea or $F$. quadrangularis with burrowing crustaceans such as Nephrops norvegicus, in fine mud at depths of between 15 and $200 \mathrm{~m}$. In the southern Bay of Biscay, we found aggregations of $F$. quadrangularis on circalittoral soft bottoms but also on the upper bathyal deeper than $200 \mathrm{~m}$. In addition, we also found aggregations of Pennatula spp. in the Galician area, all of them on circalittoral bottoms. Finally, V. mirabilis was absent and $N$. norvegicus was found at low densities in the study area, despite its general distribution between 90 and $600 \mathrm{~m}$ in the study area (ICES 2012). Other species not mentioned by OSPAR, M. sarsi, A. irregularis, $L$. depurator, Ophiura ophiura and M. intermedia, were frequent in the aggregations found in the study area. Although the southerner area and the deeper and trawling sampling in the present study marked differences from the methodology used to define this habitat in Northern Europe, and the community composition and density of the aggregations of sea pens on the northern Spanish shelf might be biased by some other factors.

Some of these frequent species, $L$. depurator, $O$. ophiura and A. irregularis, are known to be opportunistic species in trawled areas (Kaiser et al. 1998, Vergnon and Blanchard 2006, de Juan et al. 2007) like our study area which support an intensive fishing pressure (Sánchez and Olaso 2004, ICES 2012). In contrast to the North Sea, the Irish Sea and northern Bay of Biscay, where Nephrops is one of the most important fisheries, in the southern Bay of Biscay $N$. norvegicus has stopped being a target species over time due to its low abundance. Nevertheless, it is a valued component of the mixed bottom trawl fishery together with hake, anglerfish, megrim, horse mackerel, mackerel and blue whiting (Fariña and Herraiz 2003, Punzón et al. 2010, ICES 2012). The Nephrops stock is declining in the study area (Fariña and Herraiz 2003) and recovery plans were adopted in 2005 (Council Regulation (EC) 2166/2005). This decline in Nephrops stock could have coincided with a decline in sea pens in the past, which could partially explain the low densities of sea pens found in the study. Now, this mixed bottom trawling could be a similar threat for sea pens in the Cantabrian and Galician waters to that of Nephrops trawling in the North Sea, the Irish Sea and the northern Bay of Biscay, but this possibility has not been assessed. Evidences like the intensive fishing pressure, the declining Nephrops stock, the presence of opportunistic species in the aggregations and the low densities of sea pens found in the present study suggest that trawling might be affecting sea pen abundance in the southern Bay of Biscay and highlight the need for further information to assess the status of these important communities in this region.

\section{ACKNOWLEDGEMENTS}

We are grateful to all the participants of the Northern Spanish Shelf Groundfish Surveys carried out in 
the Cantabrian Sea and off Galicia and to the crew of the R/V Cornide de Saavedra. We also thank the ECOMARG and INDEMARES projects for the information on benthic communities in the Le Danois Bank MPA, the Galicia Bank and the Avilés Canyon.

The manuscript was improved thanks to the careful revision and constructive comments of Ellen Kenchington.

\section{REFERENCES}

Aguilar R., Torriente A., García S. 2009. Propuesta de Áreas Marinas de Importancia Ecológica. Zona galaico-cantábrica. Oceana-Fundación Biodiversidad, 252 pp.

Altuna Á. 2010. Listado de los cnidarios (Cnidaria) bentónicos del Golfo de Vizcaya y zonas próximas (Atlántico NE). Proyecto Fauna Ibérica. Museo Nacional de Ciencias Naturales, Madrid, $27 \mathrm{pp}$.

Baillon S., Hamel J.F., Wareham V.E., et al. 2012. Deep cold-water corals as nurseries for fish larvae. Front. Ecol. Environ. 10: 351-356. https://doi.org/10.1890/120022

Baillon S., Hamel J.F., Mercier A. 2014. Diversity, distribution and nature of faunal associations with deep-sea pennatulacean corals in the Northwest Atlantic. PloS ONE 9: e111519. https://doi.org/10.1371/journal.pone.0111519

Birkeland C. 1974. Interactions between a sea pen and seven of its predators. Ecol. Monogr. 44: 211-232. https://doi.org/10.2307/1942312

Blanchet F.G., Legendre P., Borcard D. 2008. Forward selection of explanatory variables. Ecology 89: 2623-2632. https://doi.org/10.1890/07-0986.1

BOE. 2011. Real Decreto 1629/2011, de 14 de noviembre, por el que se declara como Área Marina Protegida y como Zona Especial de Conservación el espacio marino de El Cachucho, y se aprueban las correspondientes medidas de conservación. BOE 295: 130084-130138.

Borcard D., Gillet F., Legendre P. 2011. Numerical Ecology with R. Springer, New York. https://doi.org/10.1007/978-1-4419-7976-6

Clarke K.R., Gorley R.N. 2006. PRIMER v6: User Manual/Tutorial. PRIMER-E, Plymouth.

Connor D.W., Allen J.H., Golding N., et al. 2004. The marine habitat classification for Britain and Ireland, version 04.05. JNCC, Peterborough.

de Juan S.D., Cartes J.E., Demestre M. 2007. Effects of commercial trawling activities in the diet of the flat fish Citharus linguatula (Osteichthyes: Pleuronectiformes) and the starfish Astropecten irregularis (Echinodermata: Asteroidea). J. Exp. Mar. Biol. Ecol. 349: 152-169. https://doi.org/10.1016/j.jembe.2007.05.003

de Moura Neves B., Edinger E., Layne G.D., et al. 2015. Decadal longevity and slow growth rates in the deep-water sea pen Halipteris finmarchica (Sars, 1851) (Octocorallia: Pennatulacea): implications for vulnerability and recovery from anthropogenic disturbance. Hydrobiologia 759: 147-170. https://doi.org/10.1007/s10750-015-2229-x

DFO (Fisheries and Oceans Canada). 2010. Occurrence, susceptibility to fishing and ecological function of corals, sponges and hydrothermal vents in Canadian waters. DFO Can. Sci. Advis. Sec. Sci. Advis. Rep. 2010/041.

EU (European Union). 2008. Directive 2008/56/EC of the European Parliament and of the Council of 17 June 2008, Establishing a Framework for Community Action in the Field of Marine Environmental Policy (Marine Strategy Framework Directive). Official Journal of the European Union L164: 19-40.

Fariña A.C., Herraiz I.G. 2003. Trends in catch-per-unit-effort, stock biomass and recruitment in the North and Northwest Iberian Atlantic Nephrops stocks. Fish. Res. 65: 351-360. https://doi.org/10.1016/j.fishres.2003.09.025

Fernández J.A., Bonache J., Gordillo E. 2005. Parque Nacional das Illas Atlánticas de Galicia. Recursos rurais. Serie cursos 2: 91-102.

Gili J.M., Pagès F. 1987. Pennatuláceos (Cnidaria, Anthozoa) recolectados en la plataforma continental catalana (Mediterráneo occidental). Misc. Zool. 11: 25-39.

Greathead C.F., Donnan D.W., Mair J.M., et al. 2007. The sea pens
Virgularia mirabilis, Pennatula phosphorea and Funiculina quadrangularis: distribution and conservation issues in Scottish waters. J. Mar. Biol. Assoc. U.K. 87: 1095-1103. https://doi.org/10.1017/S0025315407056238

Greathead C., González-Irusta J.M., Clarke J., et al. 2015. Environmental requirements for three sea pen species: relevance to distribution and conservation. ICES J. Mar. Sci. 72: 576-586. https://doi.org/10.1093/icesjms/fsu129

Hughes D.J. 1998. Sea pens and burrowing megafauna (volume III). An overview of dynamics and sensitivity characteristics for conservation management of marine SACs. Scott. Assoc. Mar. Sci. (UK Marine SACs Project). 105 pp.

ICES. 2010. Manual for the International Bottom Trawl Surveys in the Western and Southern Areas Revision III. Agreed during the meeting of the International Bottom Trawl Survey Working Group 22-26 March 2010, Lisbon. Addendum 2: ICES CM 2010/SSGESST: 06. 58 pp.

ICES. 2012. Report of the ICES Advisory Committee 2012. Book 7, Bay of Biscay and Atlantic Iberian waters. ICES Advice, 2012. Book 7. 205 pp.

IEO. 2014a. Caracterización ecológica del banco de Galicia. Informe final del proyecto LIFE+ INDEMARES (LIFE07/ NAT/E/000732), subproyecto LIC. IEO. Coordinación: Fundación Biodiversidad, Madrid, 237 pp.

IEO. 2014b. Caracterización ecológica del área marina del sistema de ca-ones submarinos de Avilés. Informe final área LIFE+INDEMARES (LIFE07/NAT/E/000732). IEO. Coordinación: Fundación Biodiversidad, Madrid, $243 \mathrm{pp}$.

Jouanneau J.M., Weber O., Champilou N., et al. 2008. Recent sedimentary study of the shelf of the Basque country. J. Mar. Sys. 72: 397-406. https://doi.org/10.1016/j.jmarsys.2007.03.013

Kaiser M.J., Edwards D.B., Armstrong P.J., et al. 1998. Changes in megafaunal benthic communities in different habitats after trawling disturbance. ICES J. Mar. Sci. 55: 353-361. https://doi.org/10.1006/jmsc.1997.0322

Kaiser M.J., Clarke K.R., Hinz H., et al. 2006. Global analysis and recovery of benthic biota to fishing. Mar. Ecol. Prog. Ser. 311: $1-14$. https://doi.org/10.3354/meps311001

Kenchington E., Lirette C., Cogswell A., et al. 2010. Delineating Coral and Sponge Concentrations in the Biogeographic Regions of the East Coast of Canada Using Spatial Analyses. DFO Canadian Scientific Advisory Secretariat Research Document 2010/041. iv + 207 pp.

Kenchington E., Murillo F.J., Cogswell A., et al. 2011. WG on the ecosystem approach to fisheries management Serial No. N6005 NAFO SCR Doc. 11/75.

Kenchington E., Murillo F.J., Lirette C., et al. 2014. Kernel Density Surface Modelling as a Means to Identify Significant Concentrations of Vulnerable Marine Ecosystem Indicators. PLoS ONE 9: e109365. https://doi.org/10.1371/journal.pone.0109365

Langton R.W., Langton E.W., Theroux R.B., et al. 1990. Distribution, behavior and abundance of sea pens, Pennatula aculeata, in the Gulf of Maine. Mar. Biol. 107: 463-469. https://doi.org/10.1007/BF01313430

López-González P.J., Gili J.M., Williams G.C. 2001. New records of Pennatulacea (Anthozoa: Octocorallia) from the African Atlantic coast, with description of a new species and a zoogeographic analysis. Sci. Mar. 65: 59-74. https://doi.org/10.3989/scimar.2001.65n159

López-Jamar E., Cal R.M., González G., et al. 1992. Upwelling and outwelling effects on the benthic regime of the continental shelf off Galicia, NW Spain. J. Mar. Res. 50: 465-488. https://doi.org/10.1357/002224092784797584

MacDonald D.S., Little M., Eno N.C., et al. 1996. Disturbance of benthic species by fishing activities: a sensitivity index. Aquat. Conserv. 6: 257-268.

https://doi.org/10.1002/(SICI) 1099-0755(199612)6:4 $<257::$ AID-AQC194>3.0.CO;2-7

MAGRAMA (Ministerio de Agricultura, Alimentación y Medio Ambiente). 2012. Estrategia Marina para la demarcación marina noratlántica, parte IV: descriptores del buen estado ambiental, descriptor 1: biodiversidad. Evaluación inicial y buen estado ambiental.

http://www.magrama.gob.es/es/costas/temas/estrategias-marinas/em_noratlantica.aspx

Manuel R.L. 1981. British Anthozoa. Synopses of the British Fauna (New Series). No 18. Linnean Society Academic Press, Lon- 
don, $241 \mathrm{pp}$

NOAA. 2014. Deep Sea Coral Research and Technology Program 2014 Report to Congress. NOAA, Silver Spring, MD. 54 pp.

Ocaña A., Sánchez-Tocino L., López-González P.J. 2000. Consideraciones faunística y biogeográficas de los antozoos (Cnidaria: Anthozoa) de la costa de Granada (Mar de Alborán). Zool. Baetica 11: 51-65

Olaso I. 1990. Distribución y abundancia del megabentos invertebrado en fondos de la plataforma cantábrica. Ph.D. thesis, Inst. Esp. Oceanogr.

OSPAR. 2000. Quality Status Report 2000. Region IV- Bay of Biscay and Iberian coast. OSPAR Commission, London, $123 \mathrm{pp}$.

OSPAR. 2008. Case Reports for the OSPAR List of Threatened and/or Declining Species and Habitats. OSPAR Commission, London, $261 \mathrm{pp}$.

OSPAR. 2010. Background document for seapen and borrowing megafauna communities. OSPAR Commission, London, $27 \mathrm{pp}$.

Palmer M.W. 1993. Putting things in even better order: the advantages of canonical correspondence analysis. Ecology 74: 2215-2230. https://doi.org/10.2307/1939575

Pirtle J.L. 2005. Habitat-based assessment of structure-forming megafaunal invertebrates and fishes on Cordell Bank, California. Ph.D. thesis, Univ. Washington, 74 pp.

Porporato E.M., Mangano M.C., De Domenico F., et al. 2014. First observation of Pteroeides spinosum (Anthozoa: Octocorallia) fields in a Sicilian coastal zone (Central Mediterranean Sea). Mar. Biodiv. 44: 589-592. https://doi.org/10.1007/s12526-014-0212-9

Punzón A., Hernández C., Abad E., et al. 2010. Spanish otter trawl fisheries in the Cantabrian Sea. ICES J. Mar. Sci. 67: 1-13. https://doi.org/10.1093/icesjms/fsq085

R Development Team. 2014. R: a Language and Environment for Statistical Computing. R Foundation for Statistical Computing, Vienna, Austria. http://www.R-project.org/

Sánchez F., Olaso I. 2004. Effects of fisheries on the Cantabrian Sea shelf ecosystem. Ecol. Model. 172: 151-174. https://doi.org/10.1016/j.ecolmodel.2003.09.005

Sánchez F., Serrano A., Gómez Ballesteros A.M. 2009. Photogrammetric quantitative study of habitat and benthic communities of deep Cantabrian Sea hard grounds. Cont. Shelf Res. 29: 1174-1188. https://doi.org/10.1016/j.csr.2009.01.004

Sardá R., Rossi S., Martí X., et al. 2012. Marine benthic cartography of the Cap de Creus (NE Catalan Coast, Mediterranean Sea). Sci. Mar. 76: 159-171. https://doi.org/10.3989/scimar.03101.18D

Serrano A., Sánchez F., García-Castrillo G. 2006. Epibenthic communities of trawlable grounds of the Cantabrian Sea. Sci. Mar. 70: $149-159$ https://doi.org/10.3989/scimar.2006.70s1149

Thrush S.F., Dayton K. 2002. Disturbance to Marine Benthic Habitats by trawling and Dredging: Implications for Marine Biodiversity. Ann. Rev. Ecol. Syst. 33: 449-473. https://doi.org/10.1146/annurev.ecolsys.33.010802.150515
Tixier-Durivault A., d'Hondt M.J. 1975. Les Octocoralliaires de la campagne Biaçores. Bull. Mus. Natn. Hist. Nat. Paris, Zool. 174: $1361-1433$

Vergnon R., Blanchard F. 2006. Evaluation of trawling disturbance on macrobenthic invertebrate communities in the Bay of Biscay, France: Abundance Biomass Comparison (ABC method). Aquat. Living Resour. 19: 219-228. https://doi.org/10.1051/alr:2006022

Williams G.C. 1990. The Pennatulacea of Southern Africa (Coelenterata, Anthozoa). Ann. S. Afr. Mus. Cape Town 99: 31-119.

Williams G.C. 2011. The Global Diversity of Sea Pens (Cnidaria: Octocorallia: Pennatulacea). PloS ONE 6: e22747. https://doi.org/10.1371/journal.pone.0022747

Williams G.C. 2014. Pennatulacea. In: Costello M.J., Bouchet P., et al. 2014. European Register of Marine Species. Accessed on 2014-11-21 at

http://www.marbef.org/data/aphia.php?p=taxdetails\&id=1367

\section{SUPPLEMENTARY MATERIAL}

The following supplementary material is available through the online version of this article and at the following link: http://scimar.icm.csic.es/scimar/supplm/sm04359esm.pdf

Table S1. - Pennatulacea occurring in the southern sector of the Bay of Biscay (off Spain) south of the $44^{\circ} \mathrm{N}$ parallel and Galicia after a review of the literature contrasting with our results in the study area from 1995-2010 (* data collected from 20082014). Only references with the shallow-most and deep-most data included.

Table S2. - Species composition of the aggregations of F. quadrangularis on circalittoral and upper bathyal soft bottoms and of Pennatula spp. on circalittoral soft bottoms. Taxon: A, ascidian; C, cnidarian; CR, crustacean; E, echinoderm; M, mollusc, P, polychaete worm; S, sponge. Species: * species that occur in the aggregations of $F$. quadrangularis on circalittoral soft bottoms but not in the upper bathyal soft bottoms; ** species that occur in the aggregations of $F$. quadrangularis on bathyal soft bottoms but not on circalittoral soft bottoms; *** species that occur in the aggregations of Pennatula spp. on circalittoral soft bottoms but not in the aggregations of $F$. quadrangularis on circalittoral soft bottoms. \%: percentage of frequency of occurrence (occurs in $81-100 \%$ of the samples $(\bullet \bullet \bullet), 61-80 \%(\bullet \bullet \bullet)$, $41-60 \%(\bullet \bullet), 21-40 \%(\bullet \bullet)$ and 1-20\% (•)). D: density (col/haul): A (>1000/haul), C (100-999/haul), F (10-99/haul) and O (1-9/ haul). Abbreviations used in Figure 4 appear in brackets after the species name.

Fig. S1. - Mantel correlogram for the abundance data of aggregations as a function of the geographic distance classes among the study locations. The black squares indicate significant spatial correlation.

Fig. S2. - Species accumulation curve for the locations with density at or above the threshold 10.5 sea pens/haul of $F$. quadrangularis and Pennatula spp. 
Scientia Marina 81(3)

September 2017, S1-S4, Barcelona (Spain)

ISSN-L: 0214-8358

\section{Sea pen (Pennatulacea) aggregations on the northern Spanish shelf: distribution and faunal assemblages}

Susana Ruiz-Pico, Alberto Serrano, Antonio Punzón, Álvaro Altuna, Olaya Fernández-Zapico, Francisco Velasco

Supplementary material 
S2 • S. Ruiz-Pico et al.

Table S1. - Pennatulacea occurring in the southern sector of the Bay of Biscay (off Spain) south of the $44^{\circ} \mathrm{N}$ parallel and Galicia after a review of the literature contrasting with our results in the study area from 1995-2010 (* data collected from 2008-2014). Only references with the shallow-most and deep-most data included.

\begin{tabular}{|c|c|c|c|}
\hline Species & Depth range $(\mathrm{m})$ & References & $\begin{array}{c}\text { Depth range }(\mathrm{m}) \\
\text { Present study }\end{array}$ \\
\hline \multicolumn{4}{|l|}{ Suborder Sessiliflorae Kükenthal, 1915} \\
\hline Anthoptilum grandiflorum (Verrill, 1879) & 1400 & Louzao et al. (2010) & \\
\hline Cavernularia pusilla (Philippi, 1835) & $25-100$ & Rallo et al. (1988), Altuna et al. (2008) & \\
\hline Funiculina quadrangularis (Pallas, 1766) & $100-468$ & Altuna (1994), Louzao et al. (2010) & $84-793$ \\
\hline Kophobelemnon stelliferum (Müller, 1776) & $151-1005$ & Rallo et al. (1993), Altuna (1994) & \\
\hline Protoptilum thomsoni Kölliker, 1872 & $790-1200$ & Louzao et al. (2010) & \\
\hline Umbellula lindahli Kölliker, 1874 & $896-2320$ & Gourret (1906), Thomson (1927) & \\
\hline Veretillum cynomorium (Pallas, 1766) & $15-75$ & Thomson (1929), Altuna (1994) & $50-373$ \\
\hline \multicolumn{4}{|l|}{ Suborder Subselliflorae Kükenthal, 1915} \\
\hline Pennatula aculeata Danielssen, 1860 & $161-1225$ & Gourret (1906), Louzao et al. (2010) & 793-811* \\
\hline Pennatula grandis Ehrenberg, 1834 & $1228-1980$ & Grasshoff (1982), unpublished data & \\
\hline Pennatula phosphorea Linnaeus, 1758 & $112-135$ & Grasshoff (1982), Paulmier (1997) & $133-366^{*}$ \\
\hline Pteroeides spinosum (Ellis, 1764) & $60-208$ & Thomson (1927), Urgorri et al. (2011) & $50-296$ \\
\hline Virgularia mirabilis (Müller, 1776) & $3.7-468$ & Cacabelos et al. (2009), Louzao et al. (2010) & \\
\hline Virgularia tuberculata Marshall, 1883 & No data & & \\
\hline
\end{tabular}


Table S2. - Species composition of the aggregations of $F$. quadrangularis on circalittoral and upper bathyal soft bottoms and of Pennatula spp. on circalittoral soft bottoms. Taxon: A, ascidian; C, cnidarian; CR, crustacean; E, echinoderm; M, mollusc, P, polychaete worm; S, sponge. Species: * species that occur in the aggregations of $F$. quadrangularis on circalittoral soft bottoms but not in the upper bathyal soft bottoms; ** species that occur in the aggregations of $F$. quadrangularis on bathyal soft bottoms but not on circalittoral soft bottoms; *** species that occur in the aggregations of Pennatula spp. on circalittoral soft bottoms but not in the aggregations of $F$. quadrangularis on

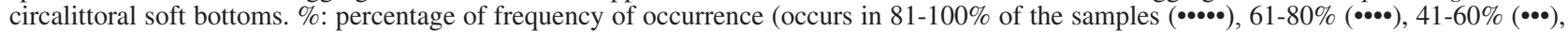
$21-40 \%(\bullet \bullet)$ and 1-20\% (•)). D: density (col/haul): A (>1000/haul), C (100-999/haul), F (10-99/haul) and O (1-9/haul). Abbreviations used in Figure 4 appear in brackets after the species name.

\begin{tabular}{|c|c|c|c|c|c|c|c|c|c|c|c|}
\hline \multicolumn{2}{|c|}{$\begin{array}{l}\text { F. quadrangularis on circalittoral } \\
\text { Taxon Species }\end{array}$} & $\%$ & $\mathrm{D}$ & \multicolumn{2}{|c|}{$\begin{array}{l}\text { F. quadrangularis on upper bathyal } \\
\text { Taxon Species }\end{array}$} & $\%$ & $\mathrm{D}$ & \multicolumn{2}{|c|}{$\begin{array}{l}\text { Pennatula spp. on circalittoral } \\
\text { Taxon Species }\end{array}$} & $\%$ & $\mathrm{D}$ \\
\hline $\mathrm{C}$ & Funiculina quadrangularis (Fqua) & $\ldots .$. & $\mathrm{C}$ & $\mathrm{C}$ & Funiculina quadrangularis (Fqua) & $\ldots$. & $\mathrm{F}$ & $\mathrm{C}$ & Pennatula spp. (Penn) & $\ldots$. & $\mathrm{F}$ \\
\hline CR & Macropodia longipes(Mlon) & $\ldots$. & $\mathrm{O}$ & M & Rossia macrosoma (Rmac) & $\ldots \ldots$ & $\mathrm{O}$ & $\mathrm{E}$ & Astropecten irregularis(Airr) & $\ldots$. & $\mathrm{F}$ \\
\hline $\mathrm{E}$ & Astropecten irregularis(Airr) & $\ldots$. & $\mathrm{F}$ & $\mathrm{E}$ & Astropecten irregularis(Airr) & $\ldots \ldots$ & $\mathrm{F}$ & M & Eledone cirrhosa (Ecirr) & $\ldots .$. & $\mathrm{F}$ \\
\hline $\mathrm{M}$ & Eledone cirrhosa (Ecirr) & $\ldots .$. & $\mathrm{O}$ & $\mathrm{CR}$ & Munida sarsi (Msar) & $\ldots$. & A & $\mathrm{M}$ & Sepia elegans (Sele) & $\ldots .$. & $\mathrm{O}$ \\
\hline $\mathrm{C}$ & Actinauge richardi (Aric) & $\ldots$ & $\mathrm{O}$ & M & Eledone cirrhosa (Ecirr) & $\cdots$ & $\mathrm{O}$ & CR & Liocarcinus depurator (Ldep) & $\ldots$. & $\mathrm{O}$ \\
\hline $\mathrm{CR}$ & Pagurus prideaux (Ppri) & $\cdots$ & $\mathrm{F}$ & CR & Macropipus tuberculatus (Mtub) & $\cdots$ & $\mathrm{C}$ & M & Sepiola sp. (Sepi) & $\cdots$ & $\mathrm{F}$ \\
\hline $\mathrm{CR}$ & Liocarcinus depurator (Ldep) & $\cdots$ & $\mathrm{F}$ & $\mathrm{CR}$ & Macropodia longipes(Mlon) & $\ldots$ & $\mathrm{O}$ & $\mathrm{M}$ & Sepia orbignyana (Sorb) & $\ldots$ & $\mathrm{O}$ \\
\hline $\mathrm{M}$ & Sepia elegans (Sele)* & $\ldots$ & $\mathrm{O}$ & $\mathrm{E}$ & Ophiura ophiura (Ooph) & $\ldots$ & $\mathrm{F}$ & $\mathrm{M}$ & Calliostoma granulatum (Cgran) & $\ldots$ & $\mathrm{O}$ \\
\hline $\mathrm{E}$ & Ophiura ophiura (Ooph) & $\ldots$ & $\mathrm{O}$ & M & Sepietta oweniana (Sowe) & $\ldots$ & $\mathrm{O}$ & $\mathrm{CR}$ & Munida intermedia (Mint) & $\ldots$ & $\mathrm{O}$ \\
\hline $\mathrm{E}$ & Parastichopus regalis (Preg) & $\ldots$ & $\mathrm{O}$ & $\mathrm{C}$ & Actinauge richardi (Aric) & $\ldots$ & $\mathrm{O}$ & $\mathrm{CR}$ & Pagurus prideaux (Ppri) & $\ldots$ & $\mathrm{F}$ \\
\hline $\mathrm{M}$ & Rossia macrosoma (Rmac) & $\ldots$ & $\mathrm{O}$ & $\mathrm{CR}$ & Liocarcinus depurator (Ldep) & $\cdots$ & $\mathrm{O}$ & M & Octopus vulgaris (Ovul) & $\ldots$ & $\mathrm{O}$ \\
\hline $\mathrm{E}$ & Leptometra celtica (Lcel) & $\cdots$ & $\mathrm{F}$ & $\mathrm{CR}$ & Pontophilus spinosus (Pspi) & $\cdots$ & $\mathrm{O}$ & $\mathrm{E}$ & Parastichopus regalis (Preg) & $\cdots$ & $\mathrm{O}$ \\
\hline $\mathrm{C}$ & Hydrozoa (Hydr) & .. & $\mathrm{O}$ & M & Scaphander lignarius (Slig) & $\ldots$ & $\mathrm{O}$ & M & Scaphander lignarius (Slig) & $\ldots$ & $\mathrm{O}$ \\
\hline $\mathrm{M}$ & Octopus salutti (Osal) & .. & $\mathrm{O}$ & $\mathrm{CR}$ & Munida intermedia (Mint) & .. & $\mathrm{O}$ & $\mathrm{M}$ & Sepietta oweniana (Sowe) & $\ldots$ & $\mathrm{O}$ \\
\hline $\mathrm{M}$ & Sepia orbignyana (Sorb) & .. & $\mathrm{O}$ & CR & Nephrops norvegicus(Nnor) & .. & $\mathrm{O}$ & $\mathrm{CR}$ & Macropodia longipes(Mlon) &.. & $\mathrm{O}$ \\
\hline CR & Munida intermedia (Mint) & .. & $\mathrm{F}$ & $\mathrm{M}$ & Octopus salutti (Osal) &.. & $\mathrm{O}$ & $\mathrm{M}$ & Neptunea contraria (Ncon) & .. & $\mathrm{O}$ \\
\hline $\mathrm{CR}$ & Munida sarsi (Msar) & .. & $\mathrm{O}$ & $\mathrm{E}$ & Parastichopus regalis (Preg) & .. & $\mathrm{O}$ & $\mathrm{CR}$ & Pagurus excavatus (Pexc) & .. & $\mathrm{O}$ \\
\hline CR & Scalpellum scalpellum (Scal) & .. & $\mathrm{O}$ & M & Sepiola sp. (Sepi) & .. & $\mathrm{F}$ & $\mathrm{CR}$ & Pagurus alatus (Pala)*** & .. & $\mathrm{O}$ \\
\hline $\mathrm{M}$ & Calliostoma granulatum (Cgran) & .. & $\mathrm{O}$ & $\mathrm{E}$ & Anseropoda placenta (Apla) &.. & $\mathrm{O}$ & CR & Pontophilus spinosus (Pspi) & .. & $\mathrm{O}$ \\
\hline $\mathrm{E}$ & Ophiotrix fragilis(Ofra) & .. & $\mathrm{O}$ & M & Bathypolipus sponsalis (Bspo)** &.. & $\mathrm{O}$ & $\mathrm{P}$ & Aphrodita aculeata (Aacu)*** & . & $\mathrm{O}$ \\
\hline $\mathrm{M}$ & Sepiola sp. (Sepi) & .. & $\mathrm{O}$ & M & Neptunea contraria (Ncon) & .. & $\mathrm{O}$ & $\mathrm{M}$ & Charonia lampas (Clam) & . & $\mathrm{O}$ \\
\hline $\mathrm{E}$ & Gracilechinus acutus (Gacu) & .. & $\mathrm{O}$ & $\mathrm{CR}$ & Pagurus alatus(Pala)** & .. & $\mathrm{O}$ & CR & Galathea intermedia (Gint) & . & $\mathrm{O}$ \\
\hline $\mathrm{CR}$ & Macropipus tuberculatus (Mtub) & . & $\mathrm{O}$ & $\mathrm{E}$ & Parastichopus tremulus (Ptre)** & .. & $\mathrm{O}$ & $\mathrm{E}$ & Leptometra celtica (Lcel) & . & $\mathrm{F}$ \\
\hline $\mathrm{C}$ & Pennatula spp. (Penn)* & . & $\mathrm{O}$ & CR & Philocheras equinulatus (Pech)** & .. & $\mathrm{O}$ & $\mathrm{M}$ & Euspira fusca (Efus) & . & $\mathrm{O}$ \\
\hline $\mathrm{E}$ & Anseropoda placenta (Apla) & . & $\mathrm{O}$ & $\mathrm{M}$ & Ranella olearium (Role) & . & $\mathrm{O}$ & $\mathrm{CR}$ & Nephrops norvegicus(Nnor) & . & $\mathrm{O}$ \\
\hline $\mathrm{CR}$ & Pagurus excavatus (Pexc)* & . & $\mathrm{O}$ & $\mathrm{E}$ & Asteronyx loveni (Alov)** & . & $\mathrm{O}$ & $\mathrm{E}$ & Ophiura ophiura (Ooph) & . & $\mathrm{O}$ \\
\hline $\mathrm{M}$ & Scaphander lignarius (Slig) & . & $\mathrm{O}$ & $\mathrm{M}$ & Buccinum sp. (Bucc)** & . & $\mathrm{O}$ & $\mathrm{M}$ & Rondeletiola minor (Rmin) & . & $\mathrm{F}$ \\
\hline M & Galeodea rugosa (Grug) & . & $\mathrm{O}$ & M & Calliostoma granulatum (Cgran) & . & $\mathrm{O}$ & M & Rossia macrosoma (Rmac) & . & $\mathrm{O}$ \\
\hline $\mathrm{M}$ & Euspira fusca (Efus)* & . & $\mathrm{O}$ & M & Colus gracilis (Cgra)** & . & $\mathrm{O}$ & $\mathrm{C}$ & Actinauge richardi (Aric) & . & $\mathrm{O}$ \\
\hline $\mathrm{CR}$ & Nephrops norvegicus(Nnor) & . & $\mathrm{O}$ & A & Diazona violacea (Dvio)** & . & $\mathrm{O}$ & A & Corella parallelogramma (Cpar) & . & $\mathrm{O}$ \\
\hline M & Octopus vulgaris (Ovul)* & . & $\mathrm{O}$ & $\mathrm{C}$ & Epizoanthus incrustatus (Einc)** & . & $\mathrm{F}$ & $\mathrm{E}$ & Echinus melo $($ Emel)*** & . & $\mathrm{O}$ \\
\hline $\mathrm{CR}$ & Pontophilus spinosus (Pspi) & . & $\mathrm{O}$ & $\mathrm{CR}$ & Galathea intermedia (Gint) & . & $\mathrm{O}$ & $\mathrm{C}$ & Funiculina quadrangularis (Fqua) & . & $\mathrm{O}$ \\
\hline $\mathrm{M}$ & Sepietta oweniana (Sowe) & . & $\mathrm{O}$ & $\mathrm{M}$ & Galeodea rugosa (Grug) & . & $\mathrm{O}$ & $\mathrm{CR}$ & Goneplax rhomboides (Grho) & . & $\mathrm{O}$ \\
\hline $\mathrm{A}$ & Corella parallelogramma (Cpar)* & . & $\mathrm{O}$ & $\mathrm{E}$ & Gracilechinus acutus (Gacu) & . & $\mathrm{O}$ & $\mathrm{E}$ & Gracilechinus acutus (Gacu) & . & $\mathrm{O}$ \\
\hline $\mathrm{CR}$ & Galathea intermedia (Gint) & . & $\mathrm{O}$ & $\mathrm{C}$ & Hydrozoa (Hydr) & . & $\mathrm{O}$ & $\mathrm{P}$ & Hyalinoecia tubicola (Htub) & . & $\mathrm{O}$ \\
\hline $\mathrm{S}$ & Phakelia ventilabrum (Pven)* & . & $\mathrm{O}$ & $\mathrm{CR}$ & Inachus dorsettensis (Idor)** & . & $\mathrm{O}$ & $\mathrm{CR}$ & Macropipus tuberculatus (Mtub) & . & $\mathrm{O}$ \\
\hline $\mathrm{M}$ & Ranella olearium (Role) & . & $\mathrm{O}$ & $\mathrm{E}$ & Leptometra celtica (Lcel) & . & $\mathrm{O}$ & $\mathrm{CR}$ & Munida sarsi (Msar) & . & $\mathrm{O}$ \\
\hline M & Rondeletiola minor (Rmin) & . & $\mathrm{O}$ & $\mathrm{CR}$ & Munida iris (Miri) & . & $\mathrm{O}$ & $\mathrm{M}$ & Octopus salutti (Osal) & . & $\mathrm{O}$ \\
\hline $\mathrm{M}$ & Sepia officinalis(Soff)* & . & $\mathrm{O}$ & $\mathrm{E}$ & Ophiotrix fragilis(Ofra) & . & $\mathrm{O}$ & $\mathrm{S}$ & Phakelia ventilabrum (Pven) & . & $\mathrm{F}$ \\
\hline $\mathrm{P}$ & Hyalinoecia tubicola (Htub)* & . & $\mathrm{O}$ & $\mathrm{CR}$ & Pagurus prideaux (Ppri) & . & $\mathrm{O}$ & $\mathrm{S}$ & Alcyonium palmatum (Apal)*** & . & $\mathrm{O}$ \\
\hline $\mathrm{CR}$ & Inachus leptochirus (Idor)* & . & $\mathrm{O}$ & $\mathrm{M}$ & Rondeletiola minor (Rmin) & . & $\mathrm{O}$ & $\mathrm{CR}$ & Cancer pagurus (Cpag) & . & $\mathrm{O}$ \\
\hline $\mathrm{E}$ & Luidia ciliaris (Lcil)* & . & $\mathrm{O}$ & $\mathrm{CR}$ & Scalpellum scalpellum (Scal) & . & $\mathrm{O}$ & $\mathrm{C}$ & Caryophyllia smithii (Csmi) & . & $\mathrm{O}$ \\
\hline $\mathrm{E}$ & Luidia sarsi (Lsar)* & . & $\mathrm{O}$ & M & Sepia orbignyana (Sorb) & . & $\mathrm{O}$ & $\mathrm{E}$ & Echinocardium cordatum (Ecor) & . & $\mathrm{O}$ \\
\hline $\mathrm{CR}$ & Munida iris (Miri) & . & $\mathrm{O}$ & & & & & $\mathrm{M}$ & Galeodea rugosa (Grug) & . & $\mathrm{O}$ \\
\hline $\mathrm{M}$ & Neptunea contraria (Ncon) & . & $\mathrm{O}$ & & & & & $\mathrm{CR}$ & Homarus gammarus (Hgra)*** & . & $\mathrm{O}$ \\
\hline M & Neopygnodonte cochlear (Ncoc)* & . & $\mathrm{O}$ & & & & & $\mathrm{CR}$ & Inachus dorsettensis (Idor)*** & . & $\mathrm{O}$ \\
\hline $\mathrm{E}$ & Brissopsis lyrifera (Blyr)* & . & $\mathrm{O}$ & & & & & $\mathrm{CR}$ & Inachus leptochirus(Ilep) & . & $\mathrm{O}$ \\
\hline $\mathrm{CR}$ & Cancer pagurus(Cpag)* & . & $\mathrm{O}$ & & & & & $\mathrm{E}$ & Luidia sarsi (Lsar) & . & $\mathrm{O}$ \\
\hline $\mathrm{C}$ & Caryophyllia smithii (Csmi)* & . & $\mathrm{O}$ & & & & & $\mathrm{E}$ & Marthasterias gracialis (Mgla) & . & $\mathrm{O}$ \\
\hline M & Charonia lampas (Clam)* & . & $\mathrm{O}$ & & & & & $\bar{M}$ & Ranella olearium (Role) & . & $\mathrm{O}$ \\
\hline $\mathrm{C}$ & Dendrophyllia cornigera (Dcor)* & . & $\mathrm{O}$ & & & & & $\mathrm{CR}$ & Scalpellum scalpellum (Scal) & . & $\mathrm{O}$ \\
\hline $\mathrm{E}$ & Echinocardium cordatum (Ecor)* & . & $\mathrm{O}$ & & & & & & & & \\
\hline $\mathrm{CR}$ & Goneplax rhomboides (Grho)* & . & $\mathrm{O}$ & & & & & & & & \\
\hline $\mathrm{E}$ & Marthasterias glacialis (Mgla)* & . & $\mathrm{O}$ & & & & & & & & \\
\hline $\mathrm{CR}$ & Polycheles typhlops (Ptyp)* & . & $\mathrm{O}$ & & & & & & & & \\
\hline $\mathrm{M}$ & Pseudosimnia carnea (Pcar)* & . & $\mathrm{O}$ & & & & & & & & \\
\hline
\end{tabular}

\section{REFERENCES}

Altuna, Á. 1994. Estudio faunístico, ecológico y biogeográfico de los cnidarios bentónicos de la costa vasca. Ph.D. thesis, Univ Navarra, 769 pp.

Altuna Á., Aguirrezabalaga F., Martínez J. 2008. An exceptional occurrence of Cavernularia pusilla (Anthozoa: Pennatulacea) off the Basque coast (south-east Bay of Biscay, north-eastern Atlantic). Mar. Biodivers. Rec. 1(e 29): 1-3

Cacabelos E., Gestoso L., Troncoso J. S. 2009. Inventario de la macrofauna bentónica de sustratos blandos de la Ensenada de San Simón (NO España). Bol. R. Soc. Esp. His. Nat. (Secc. Biol.). 103: 103-119.

Gourret P. 1906. Alcyonium palmatum, Funiculina quadrangularis, Pennatula aculeata, Kophobelemnon stelliferum, Isis (Mopsea) elongata, Muricea paucituberculata, Plexaura desiderata, Umbellula ambigua. In: Marion A.F., Étude des Coelentérés atlantiques recueillies par la Commission de dragages de l'aviso le Travailleur durant les campagnes 1880 et 1881 . Exp. Scient. Travailleur et Talisman, Paris, pp. $143-147$. 
Grasshoff M. 1982. Die Gorgonaria, Pennatularia und Antipatharia des Tiefwassers der Biscaya (Cnidaria, Anthozoa). II.-Taxonomischer Teil. Bull. Mus. Natn. Hist. Nat. Paris. (4)3(A) 4: 941-978.

Louzao M., Anadón N., Arrontes J., Álvarez-Claudio C., Fuente M., Ocharán F., Anadón A., Acuña J.L. 2010. Historical macrobenthic community assemblages in the Avilés Canyon, N Iberian Shelf: baseline biodiversity information for a marine protected area. J. Mar. Syst. $80: 47-56$.

Paulmier G. 1997. Atlas des invertébrés du Golfe de Gascogne inventoriés dans les captures des chaluts-campagnes Ressgasc 1992-1995 et Evhoe 1995. Ifremer. L'Houmeau, 100 pp, pl. 117.

Rallo A., García-Arberas L., Isasi I. 1993. Fauna macrobéntica de los fondos del cañón de Capbretón: análisis faunístico de poliquetos, crustáceos y cnidarios y caracterización de puntos de muestreo según estos descriptores. Cah. Biol. Mar. 35: 69-90.

Rallo A., Gorostiaga J.M., Saiz J.I., Isasi I. 1988. Comunidades bentónicas del Abra de Bilbao y su entorno. Cah. Biol. Mar. 29: 3-19.

Thomson J.A. 1927. Alcyonaires provenant des campagnes scientifiques du Prince Albert Ier de Monaco. Résult. Camp. Scient. Prince Albert Ier. 73: 1-77, pl. 1-6.

Thomson J.A. 1929. Alcyonaires des environs de Monaco et de localités diverses. Bull. Inst. Océanogr. Monaco. 534: 1-10.

Urgorri V., Díaz-Agras G., Besteiro C., Montoto G. 2011. Additions to the inventory of Mollusca Opisthobranchia of Galicia (NW Iberian Peninsula). Thalassas. 27: 77-100.

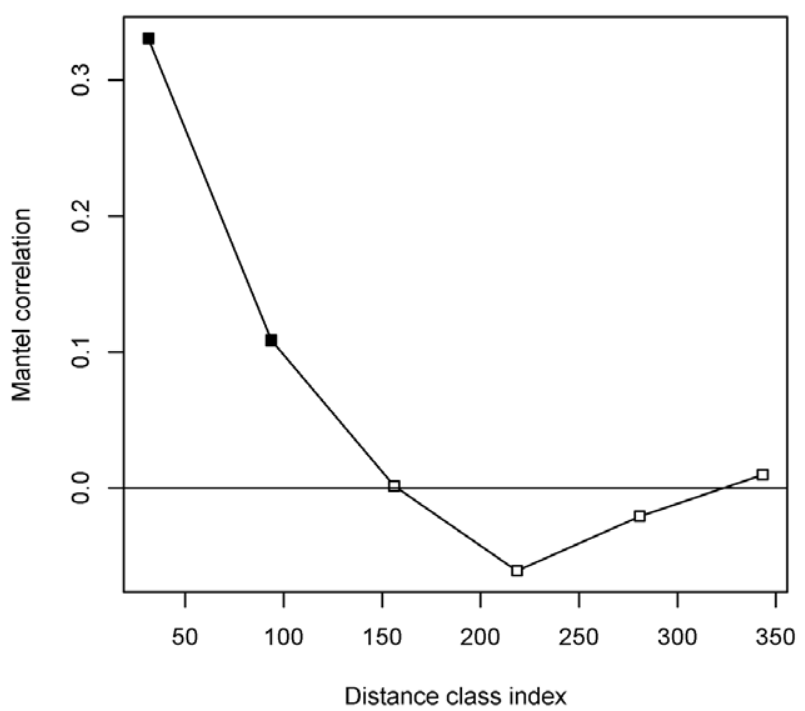

Fig. S1. - Mantel correlogram for the abundance data of aggregations as a function of the geographic distance classes among the study locations. The black squares indicate significant spatial correlation.

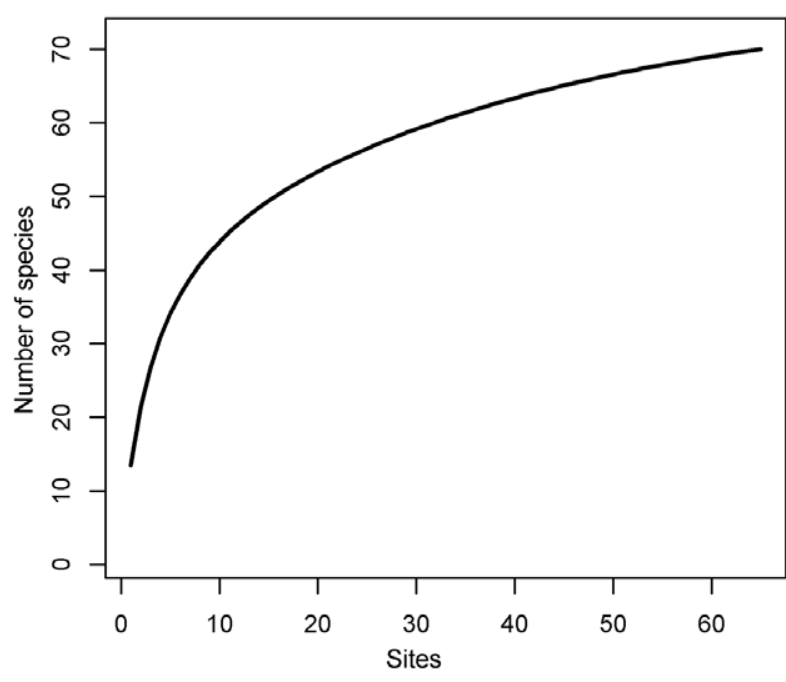

Fig. S2. - Species accumulation curve for the locations with density at or above the threshold 10.5 sea pens/haul of $F$. quadrangularis and Pennatula spp. 